\title{
Reproduction and survival of Muscina stabulans under laboratory conditions
}

\author{
Reprodução e sobrevivência de Muscina stabulans em condições de laboratório
}

\author{
Rodrigo Ferreira Krüger ${ }^{*}$ Paulo Bretanha Ribeiro ${ }^{\mathrm{I}}$ Simone Giehl Erthal $^{\mathrm{I}}$ Og DeSouza $^{\mathrm{II}}$
}

\section{-NOTE-}

\begin{abstract}
This is the first published report concerning reproduction and survival using life table analyses of fertility and survival for Muscina stabulans maintained under laboratory conditions with artificial diets. The intrinsic rate of growth, reproduction rate and average generational time were obtained, suggesting a rapid population growth under these rearing conditions. These findings permitted the creation of time models of survival and oviposition, as well as a quantitative estimate of the adaptation capacity of this species.
\end{abstract}

Key words: life table, survival analysis, population growth.

\section{RESUMO}

Com o objetivo de apresentar um primeiro delineamento para a reprodução e sobrevivência da Muscina stabulans em condições de laboratório, foram desenvolvidas tabelas de vida em dieta artificial. A taxa intrínseca de crescimento natural, a taxa reprodutiva líquida e o tempo médio de uma geração foram estimados, além da análise do tempo de oviposição e da sobrevivência dos adultos dessa espécie. Os dados sugerem uma alta taxa de crescimento da população nas condições de criação. Esses resultados permitem a criação de modelos de sobrevivência e oviposição, bem como estimativas quantitativas da adaptabilidade dessa espécie.

Palavras-chave: tabela de vida, análise de sobrevivência, crescimento populacional.

Muscina stabulans (Fallén, 1817) (Diptera, Muscidae), commonly known as the false stable fly, is a cosmopolitan, synanthropic, anautogenous species most often founded in the Neotropical Region. In Brazil it has been reported from the states of Bahia, Paraná, Rio Grande do Sul and São Paulo, preferring urban environments (CARVALHO et al., 2002). This species is epidemiologically important because it is capable of transmitting several pathogens to humans and other animals as well as causing myiasis (GREENBERG 1971). In poultry farms they can drastically reduce populations of Musca domestica Linnaeus, 1758 (Diptera, Muscidae), because $\boldsymbol{M}$. stabulans third instars are facultative predators of housefly first and second instars (SKIDMORE, 1985). This species is also forensically important since its larvae can colonize decomposing carcasses from first to 10 days following the death of the individual, thus serving in the estimation of the post-mortem interval (PMI) (CENTENO et al., 2002; SOUZA et al., 2008).

Muscina stabulans is a species with a very rapid developmental rate, especially between $20^{\circ}$ and $30^{\circ} \mathrm{C}$ (KHZYWINSKI, 1993; MARCHENKO, 2001; MASCARINI \& PRADO, 2002). In spite of this, little is known of its reproduction and survival of specific ages. This work had the objective of describing the mortality and reproduction of $\boldsymbol{M}$. stabulans using survival analysis and calculated variables obtained using fertility life tables.

\footnotetext{
IDepartamento de Microbiologia e Parasitologia, Universidade Federal de Pelotas (UFPel), CP 354, 96010-900, Pelotas, RS, Brasil. E-mail: rodrigo.kruger@ufpel.tche.br. *Autor para correspondência.

"Departamento de Biologia Animal, Universidade Federal de Viçosa (UFV), Viçosa, MG, Brasil.
} 
A colony of $\boldsymbol{M}$. stabulans was established under laboratory conditions in order to obtain eggs, larvae and pupae. The adults were maintained in $30 X 30 X 30 \mathrm{~cm}$ cages and fed powdered milk, sugar and fish meal at a ratio of 2:2:1, respectively (RIBEIRO et al., 2000b). Water was provided in cups with polyester sponges placed on the surface of the water. Feed and water were provided ad libitum. Following oviposition, egg masses were obtained from a culture medium in the form of a paste consisting of fish meal, sawdust and water in the proportion of 2:2:1, respectively. The egg masses were transferred to a receptacle with the same medium used for their collection inside a collection funnel.

After eclosion in this medium the larvae fed until the $3^{\text {rd }}$ instar, abandoned the funnel and fell into a container with moist sawdust (between 65 and 90\% $\mathrm{RH})$ to pupate. The pupae were transferred to glass containers and maintained until adult emergence. Some of these pupae were used to maintain the replacement cages in the laboratory. The colony was maintained during the entire experiment in an environmental chamber at a temperature of $24.8^{\circ} \mathrm{C} \pm 0.6^{\circ} \mathrm{C}$, relative air humidity between $70 \%$ and $80 \%$, and a12:12 hour photophase.

Life span and reproduction were determined with the establishment of 40 pairs in each cage. The four cages used were established starting with 320 randomly chosen pupae and handled in the same manner as described for the stock colony. The cages were observed daily to remove dead insects and eggs. The percent of adults surviving was recorded once a day, for 60 days, until all adults in the cage were dead. Data were submitted to survival analysis under Weibull distribution. The number of eggs laid was also recorded every day, so that in the end of the experiment such data could be transformed to reveal the daily amount of eggs laid as a proportion oh the total number of eggs. Weibull survival analysis was then applied to such data, in order to reveal the temporal pattern of oviposition. Analyses were performed under R (R DEVELOPMENT CORE TEAM, 2006) with $\mathrm{P}<0.05$.

A life table of fertility was built using the Lotka's equation (CAREY, 1993) in order to obtain the intrinsic natural growth rate $\left(\mathrm{r}_{\mathrm{m}}\right)$, mean generational time $(\mathrm{T})$, gross rate of reproduction $\left(\mathrm{Óm}_{\mathrm{X}}\right)$, and net reproductive rate $\left(\mathrm{R}_{0}\right)$. The mean time of the immature stages was obtained from the development time from egg to adult estimated by MASCARINI \& PRADO (2002) for this species. The immature survival $\left(l_{X}\right)$ was obtained using unpublished data for this species (P. B. Ribeiro personal communication).
Mortality of $\boldsymbol{M}$. stabulans differed between male and female $\left(\dot{\div}^{2}=36.3, \mathrm{df}=1, \mathrm{P}<0.001\right)$. There was a trend for mortality to occur in more advanced ages for both sexes (á>1), although females lived longer than males. Males and females reached a mean survival time of 28 and 34 days, respectively

$$
\begin{aligned}
& \left(\operatorname{Surv}_{M}=e^{-27.85465^{-3.460208}} x^{3.460208}\right. \\
& \left.\operatorname{Surv}_{F}=e^{-34.15811^{-3.460208} X^{3.460208}}\right)
\end{aligned}
$$

where Surv $_{m}$ is the proportion of surviving males and Surv $_{\mathrm{f}}$ is the proportion of surviving females (Figure 1). The mean time of oviposition was 24 days before emergence ( $\operatorname{Surv}_{\text {eqgs }}=e^{-24.50801^{-2.457002} X^{2.457002}}$ ) where Surv $_{\text {eggs }}$ is the proportion ot oviposited eggs (Figure 1).

The period of oviposition lasted 55 days, and during this time 32,806 eggs were deposited with a gross oviposition rate $\left(\mathrm{Óm}_{\mathrm{X}}\right)$ of 312 eggs per female with the highest rate of oviposition $\left(\mathrm{m}_{\mathrm{X}}\right)$ between the second and sixth week, with some oviposition occurring during the first week of the cohort. Along with the generation time of 6.41 weeks $(\mathrm{T})$, the population of this species had the capacity to increase 75.25 times in number $\left(\mathrm{R}_{0}\right)$ in stable conditions, with an increase of 0.637 individuals per individual per week $\left(\mathrm{r}_{\mathrm{m}}\right)$.

In protein-based diets such as meat or other derivatives, flies that are facultative carnivores, especially from the Subfamily Azeliinae (Muscidae) tend to exhibit similar pattern of mortality if they have used this substrate during their larval stage. The diets used by the larvae and adults of $\boldsymbol{M}$. stabulans were the same as those utilized by other species in this subfamily, such as Ophyra aenescens (Wiedemann, 1830), Ophyra albuquerquei Lopes, 1985, and Synthesiomyia nudiseta (Wulp, 1898) (HOGSETTE \& WASHINGTON, 1995; RIBEIRO et al., 2000a; KRÜGER et al., 2002; 2003). Among these species for the analysis of survival, $\boldsymbol{M}$. stabulans males and females have an mean time very similar to males and females of $\boldsymbol{S}$. nudiseta. These two species display a strong tendency for mortality to occur in more advanced ages, at the fulfillment of more than $75 \%$ of the reproductive function (KRÜGER \& ERTHAL, 2006; KRÜGER et al., 2008).

Based on our results of the demographic rates $\left(R_{0}>1\right)$, it is possible to verify that under optimal rearing conditions, this species reproduces rapidly which provides a great capacity to adapt to adverse conditions since the $r_{m}$ is high such results allowed the modeling of the population growth of M. stabulans, besides establishing a standard diet for this species.

The models for survival and reproduction will serve for the establishment of programs for study and field work for the false stable fly on the world. 


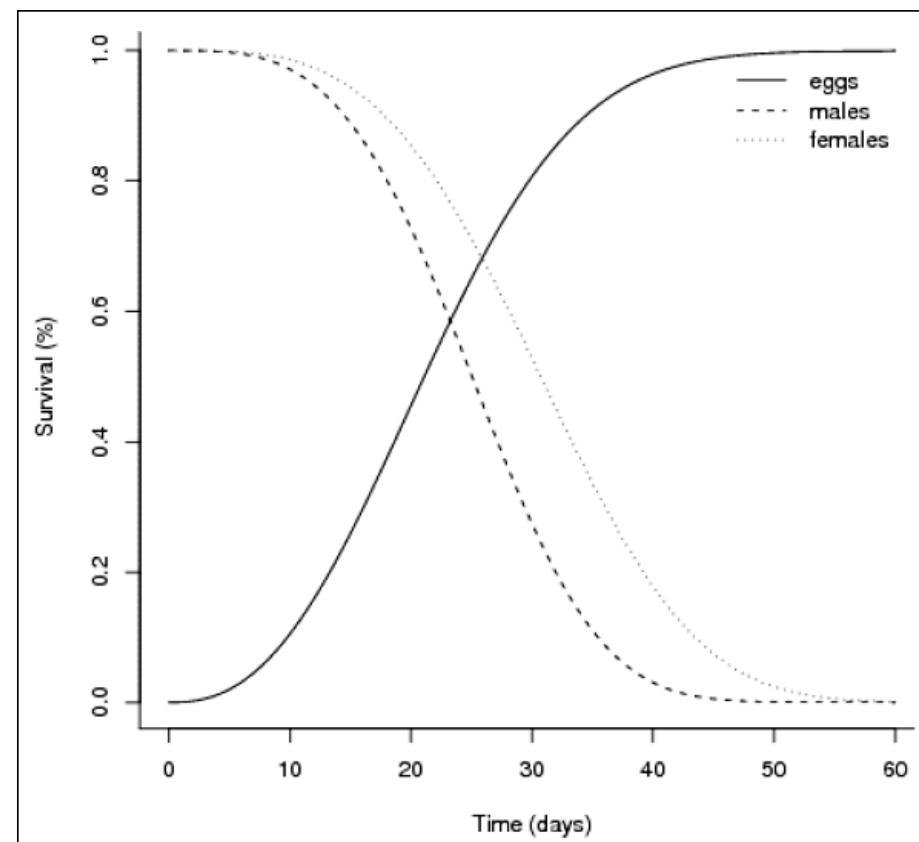

Figure 1 - Proportion of adults of Muscina stabulans (Fallén) still alive as a function of the number of days they have been caged since their emergence from pupae (dashed lines). The proportions of eggs laid by the same females (continuous lines) was superimposed to the adults survival curves. The adults were maintained at a temperature of $24.8^{\circ} \mathrm{C} \pm 0.6^{\circ} \mathrm{C}$, relative air humidity between $70 \%$ and $80 \%$, and a12:12 hour photophase. The survival models to adults and eggs proportion are: Surv ${ }_{M}=e^{-27.85465^{-3.460208}} x^{3.460208}$;

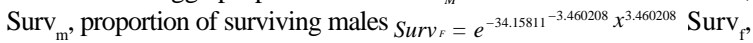

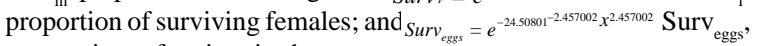
proportion of oviposited eggs.

International, v.126, p.63-70, 2002. Available from: <http://www.sciencedirect.com/ science?_ob=MImg\&_imagekey=B6T6W$\begin{array}{llllllllllll}4 & 5 & \mathrm{C} & 0 & 3 & \mathrm{~J} & 7 & - & 1 & -\end{array}$ J\&_cdi=5041\&_user $=686487 \&$ \&orig $=$ search\& _coverDate $=03 \% 2$ F $28 \% 2$ F 2002 \&_s k $=998739998 \&$ view $=c \& w c h p=d G L b V t b-$ zSkWz\&md5=89de8a42d38c6255318a928aae7729af\&ie=/ sdarticle.pdf $>$. Accessed: dec. 11, 2009. doi:10.1016/S0379-0738(02)00037-3.

GREENBERG, B. Flies and disease. Ecology, classification and biotic associations. Princeton: Princeton University, 1971. 586p.

HOGSETTE, J.A.; F. WASHINGTON. Quantitative mass production of Hydrotaea aenescens (Diptera: Muscidae). Journal of Economic Entomology, v.88, p.1238-1242, 1995.

KHZYWINSKI, J. Development of two Muscina species (Diptera, Muscidae) at constant temperature. Bulletin of Entomological Pologne, v.62, p.125-132, 1993.

KRÜGER, R.F.; ERTHAL, S.G. Estimativa de entropia de Muscina stabulans (Fallén) (Diptera, Muscidae) em condições artificiais. Revista Brasileira de Entomologia, v.50, p.275-279, 2006. Available from: <http://www.scielo.br/ scielo.php?script=sci_arttext \&pid=S0085$56262006000200009 \& \operatorname{lng}=$ en $\&$ nrm $=$ iso $>$. Accessed: dec. 11, 2009. doi: 10.1590/S008556262006000200009 .

KRÜGER, R.F. et al. Sobrevivência e reprodução de Synthesiomyia nudiseta (Wulp) (Diptera, Muscidae). Iheringia ser Zoologia, v.98,

\section{ACKNOWLEDGEMENTS}

We thank to P. H. Scholl for English language revision. R. Krüger was supported by a fellowship from Coordenação de Aperfeiçoamento de Pessoal de Nivel Superior (CAPES), O. DeSouza by the Brazilian National Council for Research (CNPq), and S. G. Erthal by the Fundaçao de Amparo a Pesquisa do Rio Grande do Sul (PBIC/FAPERGS).

\section{REFERENCES}

CAREY, J.R. Applied demography for biologists: with special emphasis on insects. New York: Oxford University, 1993. 206p.

CARVALHO, C.J.B. et al. Chave para adultos de dípteros (Muscidae, Fanniidae, Anthomyiidae) associados ao ambiente urbano no Brasil. Revista Brasileira de Entomologia, Curitiba, v.46, p.107-114, 2002. Available from: <http:// www.scielo.br/scielo.php?script=sci_arttext\&pid=S008556262002000200001\&lng=en\&nrm=iso\&tlng=pt $>$. Accessed: dec. 11, 2009. doi: 10.1590/S0085-56262002000200001.

CENTENO, N. et al. Seasonal production of arthropods occurring on sheltered and unsheltered pig carcasses in Buenos Aires Province (Argentina). Forensic Science p.45-49, 2008. Available from: <http://www.scielo.br/ s cielo.php? script =sci_art text \& pid=S 0073 47212008000100006\&lng=en\&nrm=iso\&tlng=pt $>$. Accessed: dec. 11, 2009. doi: 10.1590/S0073-47212008000100006.

KRÜGER, R.F. et al. Desenvolvimento de Synthesiomyia nudiseta (Diptera, Muscidae) em laboratório. Iheringia ser Zoologia, v.92, p.25-30, 2002. Available from: <http:// www.scielo.br/scielo.php?script=sci_arttext\&pid=S007347212002000400004\&lng=en\&nrm=iso\&tlng=pt >. Accessed: dec. 11, 2009 . doi: 10.1590/S0073-47212002000400004.

KRÜGER, R.F. et al. Desenvolvimento de Ophyra albuquerquei Lopes (Diptera, Muscidae) em condições de laboratório. Revista Brasileira de Entomologia, v.47, p.643-648, 2003. Available from: <http:// www.scielo.br/scielo.php?script=sci_arttext\&pid=S008556262003000400018\&lng=en\&nrm=iso\&tlng=pt $>$. Accessed: dec. 11, 2009. doi: 10.1590/S0085-56262003000400018.

MARCHENKO, M.I. Medico-legal relevance of cadaver fauna for the determination of the time of death. Forensic Science International, v.120, p.89-109, 2001. Available from: <http:/ / w w w. s c i e n c e d i r e c t. c o m / science?_ob=MImg\&_imagekey=B6T6W-43G30BC-J13 \&_c di $=5041$ \&_use r $=686487 \&$ \&_orig $=$ b ro w s e \&_c o ve r D a t e = $08 \% 2$ F $15 \% 2$ F 2001 \&_s k = $998799998 \&$ vi e w $=$ c \& w chp $=$ d G L z V tz - 
zSkzk\&md5=358111adf27c65cbc6cb7cd2f5e579f8\&ie =/ sdarticle.pdf $>$. Accessed: dec. 11, 2009. doi:10.1016/S03790738(01)00416-9.

MASCARINI, L.M.; A.P. PRADO. Thermal constant of an experimental population of Muscina stabulans (Fallén 1817) (Diptera: Muscidae) in the laboratory. Memórias do Instituto Oswaldo Cruz, v.97, p.281-283, 2002. Available from: <http:/ /www.scielo.br/scielo.php?script=sci_arttext\&pid=S007402762002000200026\&lng=en\&nrm=iso>. Accessed: dec. 11, 2009. Doi: 10.1590/S0074-02762002000200026.

R DEVELOPMENT CORE TEAM. R: a language and environment for statistical computing. Vienna, Austria: $\mathrm{R}$ Foundation for Statistical Computing, ISBN 3-900051-07-0. Available from: http://www.R-project.org. Accessed: may 18, 2006 .

RIBEIRO, P.B. et al. Desenvolvimento de Ophyra aenescens Wiedemann, 1830 (Diptera, Muscidae, Azeliinae), em diferentes temperaturas, em condições de laboratório. Revista Brasileira de Agrociências, v.6, p.80-87, 2000a. Available from: <http://www.ufpel.tche.br/faem/agrociencia/v6n1/ artigo17.pdf $>$. Accessed: dec. 11, 2009.

RIBEIRO, P.B. et al. Longevidade, oviposição e viabilidade pupal de Ophyra aenescens Wiedemann, 1830 (Diptera, Muscidae, Azeliinae), em condições de laboratório. Revista Brasileira de Agrociências, v.6, p.264-268, 2000b. Available from: <http://www.ufpel.tche.br/faem/agrociencia/v6n3/ artigo18.pdf $>$. Accessed: dec. 11, 2009

SKIDMORE, P. The biology of the muscidae of the world. Junk, Dordrecht: Series Entomologica, 1985. V.29, 550p.

SOUZA, A.S.B. et al. Insects of forensic importance from Rio Grande do Sul state in southern Brazil. Revista Brasileira de Entomologia, v.52, p.641-646, 2008. Available from: <http:/ /www.scielo.br/scielo.php?script=sci_arttext\&pid=S008556262008000400016\&lng=en\&nrm=iso >. Accessed: dec. 11, 2009. doi: 10.1590/S0085-56262008000400016.>. 